\title{
Ovarian Heterotopic Pregnancy Clinically Mimicking Endometrioma
}

\section{Klinik Olarak Endometriomayı Taklit Eden Ovarian Heterotopik Gebelik}

\author{
Nilüfer ONAK KANDEMIR', Figen BARUT'1, Gamze YURDAKAN', Ülkü BAYAR², Şükrü Oğuz ÖZDAMAR'
}

Departments of ${ }^{1}$ Pathology and ${ }^{2}$ Gynaecology and Obstetrics, Karaelmas University, Faculty of Medicine, ZONGULDAK, TURKEY

This study was presented as a poster in XXVIIth Congress of the International Academy of Pathology in 12-17 October 2008 in ATHENS, GREECE

\section{ABSTRACT}

Heterotopic pregnancy is a very uncommon entity with a difficult preoperative diagnosis. In the present study, we presented an ovarian heterotopic pregnancy case, clinically mimicking endometrioma developed in a 33-year-old female following an in vitro fertilization procedure. The importance of clinical, histopathological, and immunohistochemical examinations in the diagnosis of heterotopic pregnancy are emphasized.

Key Words: Ectopic pregnancy, Ovary, Endometrioma
ÖZ

Heterotopik gebelik; oldukça nadir görülen ve pre-operatif tanısı zor olan bir durumdur. Bu çalışmada 33 yaşında kadın hastada, in vitro fertilizasyon uygulamasını takiben gelişen ve klinik olarak endometrioma' y1 taklit eden ovarian heterotopik gebelik olgusu sunulmuştur. Heterotopik gebelik tanısında klinik, histopatolojik ve immünhistokimyasal incelemenin önemi vurgulanmıştır.

Anahtar Sözcükler: Ektopik gebelik, Over, Endometrioma

\section{INTRODUCTION}

Ectopic pregnancy is defined as the implantation of an embryo in a tissue other than the fundus or lower uterine segment of the endometrium. Simultaneous intra- and extrauterine (ectopic) implantation is referred to as a "heterotopic" or "combined" pregnancy. Generally, the ectopic site in a heterotopic pregnancy is the Fallopian tube. Ovarian heterotopic pregnancy is a rare condition, presenting significant diagnostic difficulties (1-5).

\section{CASE REPORT}

A 33-year-old pregnant woman who had undergone in vitro fertilization (IVF) was admitted to our out-patient obstetrics clinic complaining of vaginal bleeding during fifth gestational week. She had previously been diagnosed as mild endometriosis via laparoscopy, and had been treated with conventional ovulation induction methods for six months. At the time of admission, mild ovarian hyperstimulation syndrome was detected by laboratory and ultrasonographic examinations. The patient was followed up at monthly intervals. She was hospitalized during the 31st gestational week because of placenta previa and a caesarean

Received : 09.02.2009

Accepted : 01.04 .2009 section was subsequently performed during the 36 th week. Intraoperative determination of a hemorrhagic mass in the left ovary and a pre-diagnosis of endometrioma necessitated wedge resection. Microscopic examination revealed chorionic villous-like structures within the hematoma, along with a few isolated trophoblast-like cells and membranous structures (Figure 1A-D). Immunohistochemical analysis showed positive reactions for pan-keratin, human placental lactogen (hPL), and human chorionic gonadotropin (hCG) in the trophoblast-like cells surrounding these villous structures (Figure 2A-D). In light of the histopathological and immunohistochemical results, the case was diagnosed as an ovarian heterotopic pregnancy. The female infant delivered via caesarean section had a birth weight of $2700 \mathrm{~g}$ and an Apgar score of 2/7 and was placed under intensive care in newborn unit. The patient exhibited no complications after the operation and was discharged in good condition on the third postoperative day.

\section{DISCUSSION}

Heterotopic pregnancy, an uncommon condition, is the occurrence of concurrent intrauterine and ectopic

Correspondence: Nilüfer ONAK KANDEMİR

Department of Pathology, Karaelmas University, Faculty of Medicine, ZONGULDAK, TURKEY

E-mail: niluferkandemir@yahoo.com Phone: +90 3722610169 
implantation. The risk of heterotopic pregnancy in spontaneous pregnancies is quite low. However, the increasing frequency of assisted reproductive technologies has increased the incidence of such cases (1-8). In the present case, an ovarian heterotopic pregnancy developed in a 33-year-old female who received IVF treatment due to primary infertility. Our case is consistent with the view that heterotopic pregnancy risk is elevated in cases involving assisted reproductive technologies.

The most common site of implantation in heterotopic and ectopic pregnancies is the Fallopian tube. Although less common, implantation may also occur in the tubal fimbriae, abdominal cavity, uterine interstitium, and uterine cornua. However, ovarian heterotopic pregnancies are quite rare (19).

Ovarian heterotopic pregnancy may be clinically and radiologically confused with tubal ectopic pregnancy, hemorrhagic corpus luteum cysts, or endometriotic cysts. Ectopic pregnancy should be considered in patients who present with pelvic pain and have risk factors, regardless of whether they have menstrual irregularities. Serum beta hCG levels and a careful radiologic study are important for diagnosis $(3,5,9)$. Macroscopically, ovarian heterotopic pregnancy appears as a space-occupying hemorrhagic mass in the ovary with a blue-purple color. During surgery, approximately two-thirds of these cases are confused with hemorrhagic corpus luteum (3-6).

In the present case, no symptoms or clinical signs suggestive of ovarian heterotopic pregnancy was detected during routine prenatal check-ups. During the caesarean section performed during the 36th week of the pregnancy due to placenta previa, the discovery of a hemorrhagic mass in the left ovary and a pre-diagnosis of endometrioma prompted the surgeons to perform a wedge resectomy. The
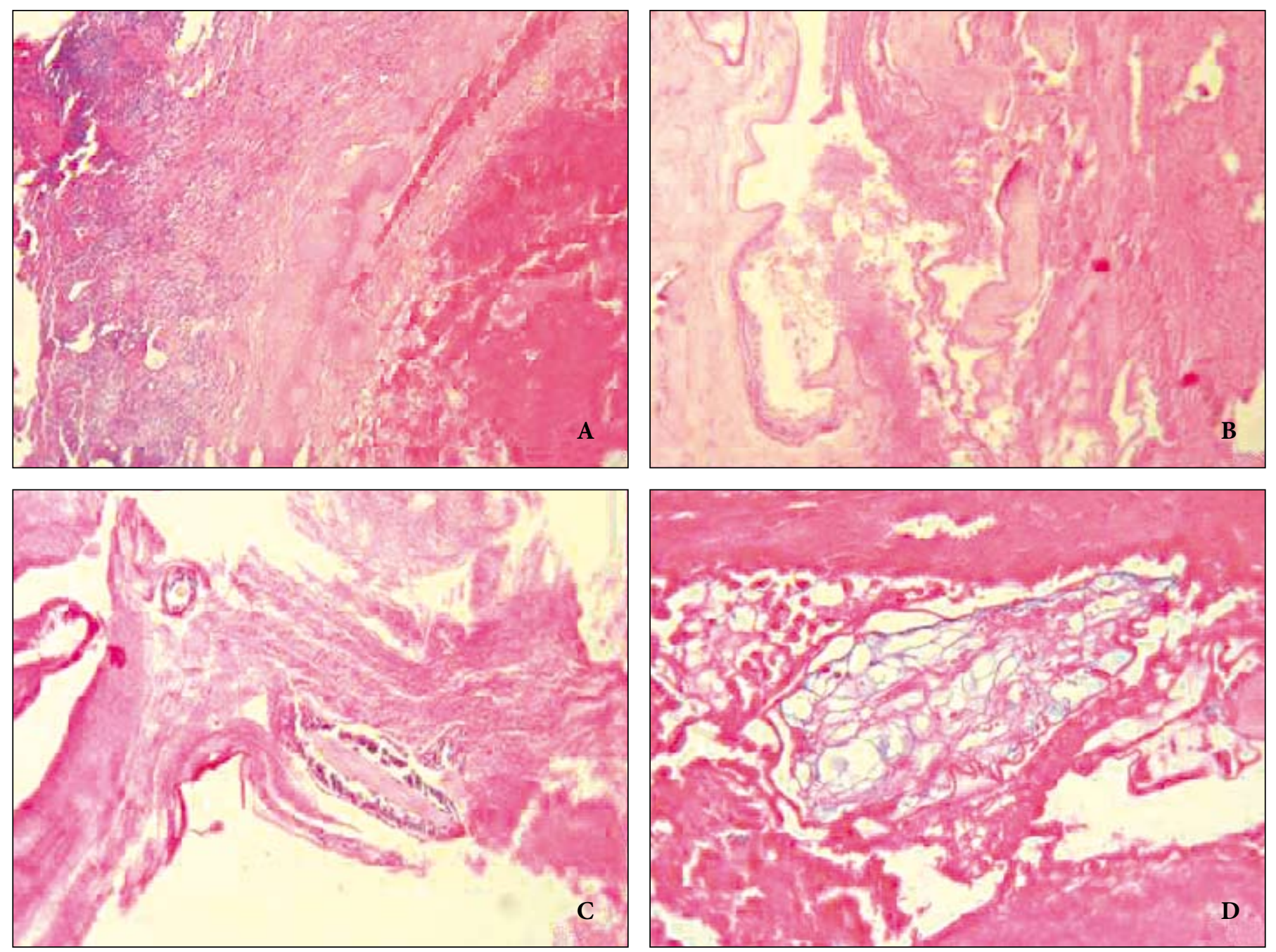

Figure 1: Degenerated chorionic villi and fetal membranes in the hematoma neighbouring the ovarian stroma $(\mathrm{H} \& \mathrm{E} ; \mathrm{A}: \times 40 ; \mathbf{B}: \times 100 ; \mathbf{C}, \mathbf{D}: \times 200)$. 

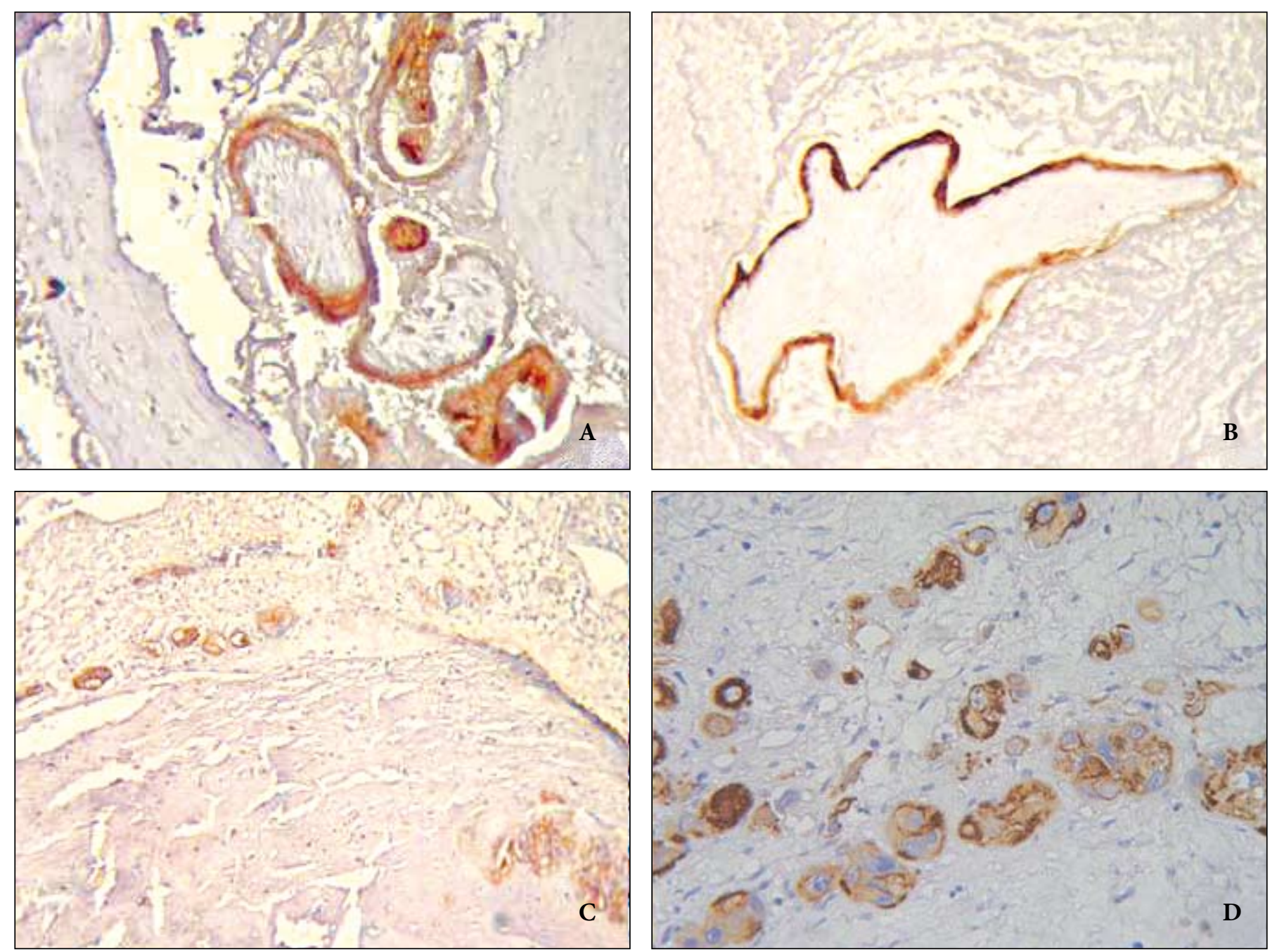

Figure 2: A,B Human chorionic gonadotropin (hCG) and C,D human placental lactogen (hPL) immunoreactivity in trophoblastic cells. (A,B: x200, C: x100, D: x400).

histomorphological features of placental tissue from the ectopic fetus were consistent with a pregnancy in its first trimester. Placental tissues appeared to be surrounded by inflammatory cells and fibrous tissue in the hematoma. The remnants of the chorionic villi were fibrotic and degenerated, and very few trophoblastic cells were observed. These findings indicate that the ovarian heterotopic pregnancy had ended in the first trimester, which is consistent with the literature, along with involution of the placental tissue. Ovarian heterotopic pregnancies typically exhibit an asymptomatic course due to ending of the pregnancy at an early stage and involution of the placental tissue.

The clinical diagnosis of heterotopic pregnancy should be supported by a histopathological diagnosis. Histopathological examination reveals chorionic villouslike structures, trophoblastic cells, and/or membranes within the hematoma. Some ectopic pregnancies may form a chronic inflammatory mass, with trophoblastic tissue involution. This condition is known as a 'chronic ectopic pregnancy, and many samples are required to detect the few degenerated villi. Demonstrating trophoblastic cells by immunohistochemical techniques contributes significantly to diagnosis (1-9).

In the present case, the histomorphological appearance was confused with an organised hematoma, due to placental tissue that had undergone involution. However, the immunohistochemical determination of keratin, hPL, hCG, and a few trophoblastic cells verified the diagnosis of ovarian heterotopic pregnancy.

Treatment of these cases is complicated by the coexisting intrauterine pregnancy. Removal of the gestational sac by laparoscopy or laparotomy is the treatment of choice. However, selective embryo reduction by direct injection 
of potassium chloride or hyperosmolar glucose into the ectopic gestational sac is another treatment option (9-13).

In conclusion, ovarian ectopic (or heterotopic) pregnancy should be considered in the differential diagnosis of hemorrhagic ovarian masses, particularly in pregnancies resulting from assisted reproductive technologies. In such cases, establishing a preoperative diagnosis is very difficult. A detailed histopathological examination and the use of immunohistochemical techniques provide important information during differential diagnosis.

\section{REFERENCES}

1. Rojansky N, Schenker JG: Heterotopic pregnancy and assisted reproduction--an update. J Assist Reprod Genet 1996, 3:594-601

2. Milicevic S, Vilendecic Z, Dokic M, Radunovic N, Stamenovic S, Stankovic A, Ljubic A: Heterotopic pregnancy: still a diagnostic puzzle. J Obstet Gynaecol 2008, 28: 458-459

3. Grimes HG, Nosal RA, Gallagher JC: Ovarian pregnancy: a series of 24 cases. Obstet Gynecol 1983, 61: 174

4. Shahabuddin AK, ChowdhuryS: Primary term ovarian pregnancy superimposed by intrauterine pregnancy: a case report. J Obstet Gynaecol Res 1998, 24:109-114

5. Melilli GA, Avantario C, Farnelli C, Papeo R, Savona A: Combined intrauterine and ovarian pregnancy after in vitro fertilization and embryo transfer: a case report. Clin Exp Obstet Gynecol 2001, 28:100-101
6. Selo-Ojeme DO, GoodFellow CF: Simultaneous intrauterine and ovarian pregnancy following treatment with clomiphene citrate. Arch Gynecol Obstet 2002, 266: 232-234

7. Anastasakis E, Jetti A, Macara L, Daskalakis G: A case of heterotopic pregnancy in the absence of risk factors. A brief literature review. Fetal Diagn Ther 2007, 22: 285-288

8. Breyer MJ, Costantino TG: Heterotopic gestation: another possibility for the emergency bedside ultrasonographer to consider. J Emerg Med 2004, 26: 81-84

9. Tay JI, Moore J, Walker JJ: Ectopic pregnancy. BMJ 2000, 320:916-919

10. Al-Sunaidi M, Tulandi T: Surgical treatment of ectopic pregnancy. Semin Reprod Med 2007, 25: 117-122

11. Pschera H, Gatterer A: Laparoscopic management of heterotopic pregnancy: a review. J Obstet Gynecol Res 2000, 3: 157-161

12. Doubilet PM, Benson CB, Frates MC, Ginsburg E: Sonographically guided minimally invasive treatment of unusual ectopic pregnancies. J Ultrasound Med 2004, 23: 359-370

13. Strohmer H, Obruca A, Lehner R, Egarter C, Husslein P, Feichtinger $W$ : Successful treatment of a heterotopic pregnancy by sonographically guided instillation of hyperosmolar glucose. Fertil Steril 1998, 69:149-151 